University of Nebraska - Lincoln

DigitalCommons@University of Nebraska - Lincoln

\title{
Reduced Translocation Is Associated with Tolerance of Common Lambsquarters (Chenopodium album) to Glyphosate
}

\author{
M. K. Yerka \\ USDA-ARS, melinda.yerka@ars.usda.gov \\ Andrew T. Wiersma \\ Colorado State University \\ R. Bradley Lindenmayer \\ Colorado State University \\ Philip Westra \\ Colorado State University, Philip.Westra@ColoState.edu \\ William G. Johnson \\ Purdue University \\ See next page for additional authors
}

Follow this and additional works at: https://digitalcommons.unl.edu/usdaarsfacpub

Yerka, M. K.; Wiersma, Andrew T.; Lindenmayer, R. Bradley; Westra, Philip; Johnson, William G.; de Leon, Natalia; and Stoltenberg, David E., "Reduced Translocation Is Associated with Tolerance of Common Lambsquarters (Chenopodium album) to Glyphosate" (2013). Publications from USDA-ARS / UNL Faculty. 1857.

https://digitalcommons.unl.edu/usdaarsfacpub/1857

This Article is brought to you for free and open access by the U.S. Department of Agriculture: Agricultural Research Service, Lincoln, Nebraska at DigitalCommons@University of Nebraska - Lincoln. It has been accepted for inclusion in Publications from USDA-ARS / UNL Faculty by an authorized administrator of DigitalCommons@University of Nebraska - Lincoln. 


\section{Authors}

M. K. Yerka, Andrew T. Wiersma, R. Bradley Lindenmayer, Philip Westra, William G. Johnson, Natalia de Leon, and David E. Stoltenberg 


\title{
Reduced Translocation Is Associated with Tolerance of Common Lambsquarters (Chenopodium album) to Glyphosate
}

\author{
Melinda K. Yerka, Andrew T. Wiersma, R. Bradley Lindenmayer, Philip Westra, William G. Johnson, Natalia de Leon, \\ and David E. Stoltenberg*
}

\begin{abstract}
Common lambsquarters tolerance to glyphosate is problematic because of the species' widespread distribution, competitive ability with many crop species, the widespread use of glyphosate in agriculture, and the weed's potential to develop decreased sensitivity to multiple herbicide sites of action. The mechanism that confers common lambsquarters tolerance to glyphosate is not known. Therefore, we conducted experiments to determine the mechanism of tolerance to glyphosate in an accession of common lambsquarters from Indiana relative to a sensitive accession from Wisconsin. The ED $\mathrm{E}_{50}(\mathrm{the}$ effective dose that reduced shoot mass $50 \%$ relative to nontreated plants) value for the tolerant accession $\left(1.6 \mathrm{~kg} \mathrm{ae} \mathrm{ha}^{-1} \pm\right.$ 0.4 standard error of the mean [SEM]) was eightfold greater than the $\mathrm{ED}_{50}$ for the sensitive accession $\left(0.2 \mathrm{~kg} \mathrm{ae} \mathrm{ha}^{-1} \pm\right.$ 0.2 SEM) $28 \mathrm{~d}$ after treatment. The glyphosate target-site (EPSPS) DNA sequence at proline 106, shikimate accumulation as an estimate of EPSPS sensitivity, and EPSPS protein abundance did not differ between accessions. Absorption of ${ }^{14} \mathrm{C}-$ glyphosate was slightly greater in the tolerant accession than it was in the sensitive accession at 48 and $72 \mathrm{~h}$ after treatment (HAT). However, the tolerant accession translocated a smaller percentage of absorbed ${ }^{14} \mathrm{C}$-glyphosate to the tissue above the treated leaf, which included the shoot apical meristem, at 24, 48, and $72 \operatorname{HAT}(\mathrm{P} \leq 0.05,0.01$, and 0.10 , respectively). These results suggest an important role of reduced translocation in conferring tolerance of common lambsquarters to glyphosate.
\end{abstract}

Nomenclature: EPSPS, 5-enolpyruvylshikimate-3-phosphate synthase; glyphosate; common lambsquarters, Chenopodium album L. CHEAL.

Key words: Herbicide, mechanism of action, resistance.

Common lambsquarters is considered one of the world's worst weeds due in part to its global occurrence and evolved resistance to photosystem II inhibitors, acetolactate synthase (ALS) inhibitors, and synthetic auxins (Heap 2012). Common lambsquarters is highly competitive with many crop species, including corn (Zea mays L.) (Moechnig et al. 2003) and soybean [Glycine max (L.) Merr.] (Conley et al. 2003; Kruger et al. 2009). Plants can produce more than 150,000 seeds (Harrison 1990), and seeds can remain viable in the soil for more than $20 \mathrm{yr}$ (Conn and Werdin-Pfisterer 2010). It is a hexaploid $(2 n=54)$ weed (Bhargava et al. 2006; Darmency and Gasquez 1990) and is predominantly self-pollinating (Holm et al. 1977), but cross-pollination likely plays an important role in gene flow (Yerka et al. 2012).

In recent years, some accessions of common lambsquarters in the United States have shown variable or inconsistent response to glyphosate (Hite et al. 2008; Kniss et al. 2007; Sivesind et al. 2011; Westhoven et al. 2008). Among glyphosate-tolerant accessions, those from Indiana have been studied for both sensitivity to glyphosate and fitness (relative reproductive success) of plants bearing the tolerance trait. Tolerance implies that there was no selection by glyphosate for plant tolerance, i.e., tolerance is due to natural phenotypic variation (the sum of genotypic and environmental variation) within the species (WSSA 1998). In greenhouse dose-response studies, the Indiana accessions were 2.6- to 5.6-fold more

\footnotetext{
DOI: 10.1614/WS-D-12-00153.1

* First, sixth, and seventh authors: Graduate Student, Assistant Professor, and Professor, Department of Agronomy, University of Wisconsin-Madison, 1575 Linden Drive, Madison, WI 53705; second, third, and fourth authors: Graduate Student, Graduate Student, and Professor, Bioagricultural Science and Pest Management, Colorado State University, Fort Collins, CO 80523-1170; fifth author: Professor, Department of Botany and Plant Pathology, Purdue University, West Lafayette, IN 47909. Current address of first author: Grain, Forage \& Bioenergy Research Unit, Agricultural Research Service, U.S. Department of Agriculture, 135 Keim Hall, East Campus, University of Nebraska, Lincoln, NE 68583-0937. Corresponding author’s E-mail: destolte@wisc.edu
}

tolerant to glyphosate, compared to sensitive control plants, based on $\mathrm{GR}_{50}$ (the herbicide dose that reduced shoot growth $50 \%$ compared to nontreated plants) values. Further, no fitness penalty was associated with this trait, based on seed production estimates (Westhoven et al. 2008).

Glyphosate is a potent inhibitor of the nuclear-encoded chloroplast EPSPS, a key enzyme in the shikimate pathway (Amrhein et al. 1980). Inhibition of EPSPS by glyphosate disrupts the production of the aromatic amino acids tyrosine, phenylalanine, and tryptophan, ultimately causing plant death. In addition, shikimate accumulates in plants when glyphosate competes for binding sites on EPSPS with phosphoenolpyruvate, a substrate in the reaction EPSPS catalyzes. Unused shikimate-3-phosphate subsequently converts to shikimate more quickly than it can be used in other metabolic pathways (Herrmann and Weaver 1999). However, a missense mutation in the gene that codes for EPSPS (EPSPS) at the codon for proline 106 ( Pro $\left._{106}\right)$ of the amino acid sequence of EPSPS, based on the petunia (Petunia sp.) reference sequence, can alter the target site such that glyphosate binding affinity to the enzyme is reduced, conferring resistance to glyphosate.

Resistance to glyphosate has to date been attributed to one or more of three mechanisms (Shaner et al. 2012): (1) an altered EPSPS target site (Powles and Yu 2010), (2) changes in vacuolar sequestration (Ge et al. 2010) or reduced translocation of glyphosate to meristematic tissues where EPSPS is primarily expressed (Shaner 2009), and (3) gene amplification of EPSPS resulting in increased wild-type EPSPS abundance (Gaines et al. 2010). Altered target-site and translocation mechanisms are typically inherited as a dominant or incompletely dominant nuclear trait (Powles and Preston 2006; Powles and Yu 2010). EPSPS amplification is also heritable. $F_{1}$ plants from a cross between a resistant male parent with EPSPS amplification and a sensitive female parent without EPSPS amplification were resistant to glyphosate, and 
both EPSPS protein abundance and the resistant phenotype segregated in $F_{2}$ plants (Gaines et al. 2010).

An altered EPSPS tends to confer low-level resistance to glyphosate (two- to fourfold compared to sensitive control plants), whereas changes in sequestration, translocation, or increased EPSPS abundance tend to provide higher levels of resistance (8- to 12-fold compared to sensitive control plants) (Powles and Yu 2010; Shaner 2009). Furthermore, increased EPSPS abundance (Gaines et al. 2010) and altered translocation (Shaner 2009) have been associated with decreased shikimate accumulation in resistant plants.

Tolerance of common lambsquarters to glyphosate is problematic because of the widespread use of glyphosate in agriculture; the plant's ability to compete with crops, resulting in reduced yields; and the weed's potential for selection of decreased sensitivity to multiple herbicide sites of action. The mechanism that confers common lambsquarters tolerance to glyphosate is not known. Elucidating the mechanism or mechanisms of common lambsquarters tolerance to glyphosate is important for our understanding of the diversity of resistance mechanisms within and among species and may help facilitate proactive resistance-management strategies to reduce the persistence and spread of resistance that threatens cropping systems around the world. Therefore, we conducted experiments to quantify the whole-plant dose-response of glyphosatetolerant (Indiana) and glyphosate-sensitive (Wisconsin) accessions of common lambsquarters and to determine the roles of the EPSPS target site's sensitivity, mutation of the target site, EPSPS protein abundance, and absorption and translocation of glyphosate in conferring tolerance.

\section{Materials and Methods}

Plant Materials. A glyphosate-tolerant common lambsquarters accession (hereafter referred to as $\mathrm{T}$ ) collected near Huntington, IN, with 3.7-fold tolerance to glyphosate relative to sensitive control plants collected near Jefferson, IN (about $161 \mathrm{~km}$ from Huntington, IN; Westhoven et al. 2008), was used in all experiments. Seed from glyphosate-sensitive common lambsquarters was not available from the Huntington, IN, site. Consequently, the response of $\mathrm{T}$ plants and sensitive plants from that site to glyphosate could not be compared nor could the evolutionary pressure(s) behind the $\mathrm{T}$ phenotype be determined. Instead, the $\mathrm{T}$ accession was compared with a sensitive accession from a long-term experiment established in 1998 at the University of Wisconsin Arlington Agricultural Research Station (AARS) near Arlington, WI, with no history of exposure to glyphosate (hereafter referred to as $S$ ). Previous research had shown that glyphosate sensitivity of the $S$ accession did not differ from that of five other accessions from treatments in the same AARS experiment with known glyphosate-use histories (Yerka 2011). Thus, the response of the $T$ accession to glyphosate was compared in this research with that of an $S$ accession whose sensitivity to glyphosate was typical among other glyphosate-sensitive common lambsquarters accessions.

Whole-Plant Dose-Response. The relative response of T and $S$ accessions to glyphosate was determined in experiments conducted at the University of Wisconsin-Madison using greenhouse-grown plants. Seeds from each accession were sown and covered with $2 \mathrm{~mm}$ of commercial potting medium
(Metro Mix 300 potting medium, Scott-Sierra Horticultural Products Co., 14111 Scottslawn Road, Marysville, $\mathrm{OH}$ 43041) in separate 265 - by 265 - by $55-\mathrm{mm}$ (length by width by height) plastic trays. Seed dormancy was broken by thoroughly drenching the media with $100 \mathrm{mg} \mathrm{L}^{-1}$ ethephon (2-chloroethylphosphonic acid; Bayer CropScience AG, Alfred-Nobel-Str. 50, D - 40789 Monheim am Rhein, Germany) delivered in a balanced fertilizer (Peter's Professional Fertilizer; Everris International B.V., P.O. Box 40, 4190 CA Geldermalsen, The Netherlands) with 300 ppmv N (Saini et al. 1986). Seeds were maintained at $22 \mathrm{C}$ in the dark for $48 \mathrm{~h}$ until uniform emergence was observed and subsequently transferred to a $16 / 24 \mathrm{C}$ day/night temperature regime with a 16-h photoperiod of natural light supplemented with artificial light $(1,000-\mathrm{W}$ high-pressure sodium light; P. L. Light System, Inc. 4800 Hinan Drive, Beamsville, ON, Canada L0R 1B1). Seedlings were transplanted individually into 10 -cm-diam plastic pots $\left(45 \mathrm{~cm}^{3}\right)$ containing commercial potting media at the cotyledon stage. Seedlings were watered daily and fertilized weekly to prevent moisture or nutrient deficiencies.

$\mathrm{T}$ and $\mathrm{S}$ plants between 10 - and $15-\mathrm{cm}$ tall (about seven nodes) were treated with glyphosate (Roundup WeatherMAX; Monsanto Company, 800 N. Lindburgh Blvd., St. Louis, MO 63167) at $0.10,0.21,0.42,0.84,3.36,6.72$, and $16.8 \mathrm{~kg} \mathrm{ae} \mathrm{ha}^{-1}$, and a nontreated check for each accession was included as well. All treatments included $20 \mathrm{~g} \mathrm{~L}^{-1}$ ammonium sulfate (AMS). Glyphosate was applied with a stationary pot sprayer equipped with an even, flat-fan spray nozzle calibrated to deliver $187 \mathrm{~L} \mathrm{ha}^{-1}$ spray solution at the level of the plant canopy. After treatment, plants were returned to the greenhouse and maintained in environmental conditions as described above. Shoot mass was harvested $28 \mathrm{~d}$ after treatment, dried at $60 \mathrm{C}$ until constant mass was observed, and weighed.

The experimental design was completely randomized with four replications of each treatment, and three experiments were conducted. Dry-mass data were converted to a percentage of the nontreated check and were subjected to nonlinear regression in PROC NLIN of SAS software (version 9.2; SAS Institute Inc., 100 SAS Campus Drive, Cary, NC 27513) using the following common, three-parameter loglogistic equation:

$$
Y=d /\left\{1+\exp \left[b\left(\log x-\log \mathrm{ED}_{50}\right)\right]\right\}
$$

where $d$ is the upper asymptote (\%), $\mathrm{ED}_{50}$ is the effective dose $\left(\mathrm{kg}\right.$ ae $\mathrm{ha}^{-1}$ ) that reduced shoot mass 50\% relative to nontreated plants, and $b$ is the slope of the curve at the $\mathrm{ED}_{50}$ (Ritz 2010; Stoltenberg and Wiederholt 1995). Confidence intervals $(95 \%)$ were used to determine whether $\mathrm{ED}_{50}$ values of $\mathrm{T}$ and $\mathrm{S}$ accessions differed and to determine experiment by accession interactions. If model parameters did not differ between experiments within accession, data from experiments were pooled for analysis.

EPSPS Sensitivity to Glyphosate. To estimate differences in EPSPS sensitivity between $T$ and $S$ accessions, shikimate accumulation in response to glyphosate was measured in experiments conducted at Colorado State University. Seeds from each accession were sown in separate 555 - by 265 - by $55-\mathrm{mm}$ (length by width by height) plastic trays in commercial potting medium (Metro Mix 300 potting 
medium; Sun Gro Horticulture Canada CM Ltd.), and dormancy was broken with an ethephon drench as described above. Plants were maintained in the greenhouse under ambient temperature and light conditions following emergence, watered daily, and fertilized (Miracle-Gro Water Soluble All Purpose Plant Food; Scotts Miracle-Gro Products, Inc., P.O. Box 606, Marysville, OH 43040) weekly.

A shikimate bioassay was conducted following the methods of Shaner et al. (2005). Seven replicate, 4-mm-dia leaf discs from each accession were placed in individual wells of a 96well microtiter plate (Nunc Microwell 96-well plate; VWR International Inc., 17750 East 32nd Place, Suite 10, Aurora, CO 80011) to which 100- $\mu$ of glyphosate treatment solutions ranging from 0 to $1,200 \mu \mathrm{M}$ were added (seven leaf discs per glyphosate treatment per accession). Following incubation in light $\left(150 \mu \mathrm{mol}\right.$ photons $\left.\mathrm{m}^{-1} \mathrm{~s}^{-1}\right)$ at $20 \mathrm{C}$ for $16 \mathrm{~h}$, shikimate was extracted from leaf discs and quantified spectrophotometrically. A shikimate standard curve was developed by adding known amounts of shikimate to wells containing leaf discs not exposed to glyphosate so that shikimate levels could be reported as micrograms of shikimate per milliliter of solution (Shaner et al. 2005). The experiment was conducted twice. Shikimate data were subjected to nonlinear regression in GraphPad Prism 5 (GraphPad Software, Inc., Avenida de la Playa, La Jolla, CA 92037) using the following common, three-parameter log-logistic equation:

$$
Y=c+(d-c) /\left(1+10^{\log \mathrm{ED}_{50}-\log x}\right)
$$

where $c$ is the lower asymptote $\left(\mu \mathrm{g} \mathrm{ml} l^{-1}\right), d$ is the upper asymptote $\left(\mu \mathrm{g} \mathrm{ml}^{-1}\right)$, and $\mathrm{ED}_{50}$ is the effective dose $(\mu \mathrm{M})$ that increased shikimate accumulation $50 \%$ relative to nontreated plants. Confidence intervals (95\%) were used to determine whether $\mathrm{ED}_{50}$ values of $\mathrm{T}$ and $\mathrm{S}$ accessions differed and to determine experiment by accession interactions as described above.

EPSPS Pro ${ }_{106}$ Sequencing. To determine whether a Pro $_{106}$ mutation in EPSPS was associated with tolerance of the T accession to glyphosate, total DNA was extracted from 10 plants of both $\mathrm{T}$ and $\mathrm{S}$ accessions in experiments conducted at the University of Wisconsin-Madison using the hexadecyltrimethylammonium bromide (CTAB) procedure (Rogers and Bendich 1985) with some modifications. Young leaf tissue $(100 \mathrm{mg})$ was collected from each plant, placed in a 2$\mathrm{ml}$ microcentrifuge tube, and flash frozen in liquid nitrogen until DNA was extracted. Individual samples were removed from liquid nitrogen, quickly ground in the collection tube with a micropestle, suspended in $1,000 \mu \mathrm{l}$ of $2 \times \mathrm{CTAB}$ extraction buffer with $0.001 \% \beta$-mercaptoethanol $(\mathrm{v} / \mathrm{v})$, and vortexed thoroughly. Tissue was kept frozen before suspension in extraction buffer. Samples were incubated in a $65 \mathrm{C}$ water bath for $1 \mathrm{~h}$ and inverted gently every $15 \mathrm{~min}$; after which, $400 \mu \mathrm{l}$ of chloroform : 1 -octanol $(24: 1)$ was added. Samples were vortexed and centrifuged at $1,180 \times g$ for $5 \mathrm{~min}$. The aqueous phase was transferred to a new $1.5-\mathrm{ml}$ microcentrifuge tube and a second $400-\mu \mathrm{l}$ aliquot of chloroform : 1octanol $(24: 1)$ was added. Samples were vortexed and centrifuged at $1,180 \times g$ for $5 \mathrm{~min}$. The aqueous phase was transferred to a new $1.5-\mathrm{ml}$ microcentrifuge tube, and $300 \mu \mathrm{l}$ of isopropanol was added. Samples were mixed gently by inversion to precipitate the DNA and centrifuged at $14,500 \times$ $g$ for $5 \mathrm{~min}$ to form a pellet. The aqueous phase was poured off, and $500 \mu \mathrm{l}$ of $70 \%$ ethanol was added. Samples were vortexed and centrifuged at $14,500 \times g$ for $5 \mathrm{~min}$. The ethanol was poured off, and samples were placed in a fume hood until residual ethanol had evaporated (about $5 \mathrm{~min}$ ). Pellets were resuspended in $125 \mu \mathrm{TE}(\mathrm{pH}$ 7.6) with $0.0001 \%(\mathrm{v} / \mathrm{v})$ ribonuclease A (RNase A, 7,000 $\mathrm{U} \mathrm{ml}^{-1}$ ). DNA quantity and quality were verified spectrophotometrically on a NanoDrop (Thermo Fisher Scientific Inc., 3747 N Meridian Road, Rockford, IL 61101). Samples were stored at $-20 \mathrm{C}$ until polymerase chain reaction (PCR) was performed.

Degenerate primers for EPSPS were designed from alignments of complementary DNA (cDNA) or messenger RNA (mRNA) sequences of rigid ryegrass (Lolium rigidum Gaudin; GenBank AF349754.1), rice (Oryza sativa L.; GenBank AF413082.1), Arabidopsis thaliana (L.) Heynh.; GenBank AK227120.1, cultivated tobacco (Nicotiana tabacum L.; GenBank M61904.1), kidney bean (Phaseolus vulgaris L.; GenBank DQ813667.1), and Palmer amaranth (Amaranthus palmeri S. Wats.; GenBank FJ861242.1) using the ClustalW (European Bioinformatics Institute, Hinxton, Cambridge, UK) multiple alignment application of the BioEdit Sequence Alignment Editor (7.0.9; Ibis Biosciences, Carlsbad, CA 92008) (Hall 1999). A novel forward primer, CHEAL FP106 (5'- TTCTTTATATGCTGGATGCTTTAAGA-3'), and reverse primer, CHEAL R-P106 (5'-TAGTATAGAGAATAGAAGAACATTAAACAGC-3') were subsequently developed to amplify a 300-bp sequence of EPSPS, including the $\mathrm{Pro}_{106}$ codon. The sequence was PCR-amplified on a thermocycler from total DNA using Platinum $P f x$ DNA Polymerase (Invitrogen Corporation, 5791 Van Allen Way, PO Box 6482, Carlsbad, CA 92008), a high-fidelity enzyme, according to the manufacturer's instructions with the following modifications. Each PCR reaction was $50 \mu \mathrm{l}$ and contained 7.5X Pfx Amplification Buffer, $0.3 \mathrm{mM}$ of each deoxyribonucleotide triphosphate (dNTP), $1 \mathrm{mM}$ of $\mathrm{MgSO}_{4}, 1,600 \mathrm{ng}$ of template DNA, 1,000 ng of each primer, 1 unit of Platinum Pfx DNA polymerase, and $1 \times \mathrm{PCR}_{x}$ Enhancer Solution, with autoclaved, distilled water to volume. The PCR amplicons were visualized with $2 \%$ agarose gel electrophoresis and directsequenced by Sanger sequencing on an ABI 3730xl DNA Analyzer (Applied Biosystems, Life Technologies Corporation, 5791 Van Allen Way, P.O. Box 6482, Carlsbad, CA 92008). T and S EPSPS sequence was aligned with the cDNA and mRNA sequences of the species listed above as described.

EPSPS Protein Abundance. Relative EPSPS abundance in T and $S$ accessions was determined in experiments conducted at Colorado State University using a polyclonal anti-EPSPS antibody from Monsanto. The antibody was originally developed in rabbits by Strategic Biosolutions (now SDIX, 111 Pencader Drive, Newark DE 19702-3322) against purified, transgenic corn TIPA-EPSPS, a variant of the EPSPS enzyme bearing a threonine-to-isoleucine substitution (TI) at position 102 and a proline-to-alanine substitution (PA) at Pro $_{106}$ (R. Douglas Sammons, personal communication). TIPA-EPSPS was produced in Escherichia coli with pMON 42481 with a polyhistidine tag on the carboxy terminus for rapid purification.

Plants were grown under greenhouse conditions as described above. Immunoblotting was performed using the methods of Bolt and Mahoney (1997) with minor modifications. Aboveground plant tissue from 2.5- and 8-cm-tall common lambsquarters was 
ground in liquid nitrogen using a mortar and pestle, and protein extraction was performed with a $1: 4$ ratio of tissue : laemmli buffer (Laemmli 1970). Samples were boiled for $2 \mathrm{~min}$ and centrifuged at $16,900 \times g$ for $5 \mathrm{~min}$. Protein remaining in the supernatant was quantified spectrophotometrically by light extinction at $570 \mathrm{~nm}$ (Protein Quantification Assay User Manual Rev. 02; Macherey-Nagel GmbH \& Co. KG, NeumannNeander-Str. 6-8, Düren, Germany). Protein concentrations were normalized to $2.5 \mu \mathrm{g}$ protein $\mu^{-1}$ across samples, and $10-\mu \mathrm{l}$ aliquots were resolved by $10 \%(\mathrm{w} / \mathrm{v})$ sodium dodecyl sulfatepolyacrylamide gel electrophoresis (SDS-PAGE) at $20 \mathrm{~mA}$ per gel for approximately $1 \mathrm{~h}$. Five positive controls were included from glyphosate-resistant Palmer amaranth with approximately 85 copies of EPSPS relative to a reference gene (Gaines et al. 2010), glyphosate-resistant kochia [Kochia scoparia (L.) Schrad.] with eight, seven, and five relative copies of EPSPS, respectively (unpublished data); and glyphosate-sensitive kochia with a single relative copy of EPSPS. Common lambsquarters, Palmer amaranth, and glyphosate-sensitive kochia lanes contained $25 \mu \mathrm{g}$ protein lane $e^{-1}$, whereas glyphosate-resistant kochia lanes contained $12.5 \mu \mathrm{g}$ protein lane ${ }^{-1}$, such that band intensity corresponded to approximately 4, 3.5, and 2.5 copies of EPSPS, respectively. Although it had not been determined whether EPSPS gene copy number corresponded to a one-to-one increase in the amount of EPSPS protein present, these samples represented a broad range of EPSPS protein abundance and, thus, served to ensure the sensitivity of the immunoblot assay to differential EPSPS concentrations. Such sensitivity was necessary to provide a qualitative, if not quantitative, basis of comparison of target-site abundance between $\mathrm{T}$ and $\mathrm{S}$ common lambsquarters in the absence of expression data that would require molecular markers specific to each diploid genome in this hexaploid species.

Protein was transferred for $1 \mathrm{~h}$ at $300 \mathrm{~mA}$. Nitrocellulose membranes (Osmonics NitroBind nitrocellulose transfer membranes, 0.45 Mm; GE Water and Process Technologies, 4636 Somerton Road, Feasterville-Trevose, PA 19053; http:// www.gewater.com/index.jsp) were blocked for $16 \mathrm{~h}$ at $4 \mathrm{C}$ in TBST (20 mM Tris base [pH 7.5], $0.5 \mathrm{M} \mathrm{NaCl}, 0.05 \%$ Tween 20 [Sigma-Aldrich Co. LLC., 3050 Spruce Street, St. Louis, MO 63103]) containing 5\% milk powder (w/v). Membranes were incubated for $1 \mathrm{~h}$ at $20 \mathrm{C}$ with the antiEPSPS primary antibody (Gaines et al. 2010) diluted at $1: 2,000$ in TBST. Membranes were rinsed three times in TBST and incubated in a $1: 10,000$ dilution of secondary antibody (goat-rabbit) conjugated with horseradish peroxidase (ImmunoPure Antibody; Thermo Fisher) at $20 \mathrm{C}$ for $1 \mathrm{~h}$. Membranes were rinsed three times in TBST. Activator solution (SuperSignal West Pico Chemiluminescent Substrate; Thermo Fisher) was applied to activate chemiluminescence. Film was exposed for $16 \mathrm{~h}$ and developed to visualize bands. To ensure equal amounts of protein were loaded for each sample, duplicate gels were stained using Coomassie Brilliant Blue (Thermo Fisher) and mounted on cellulose membranes.

Glyphosate Absorption, Translocation, and Exudation from Roots. Absorption, translocation, and root exudation of ${ }^{14} \mathrm{C}$-glyphosate in $\mathrm{T}$ and $\mathrm{S}$ accessions were quantified in experiments conducted at Colorado State University using plants as described in the "EPSPS Sensitivity to Glyphosate" section above, except that seedlings were transplanted when $2.5 \mathrm{~cm}$ tall into $4.2-\mathrm{cm}$-dia by $20.5-\mathrm{cm}$-deep plastic pots filled with sand to facilitate the recovery of root tissue. The fourth youngest leaf of 10-cm-tall (approximately seven nodes) plants was covered with aluminum foil. Formulated glyphosate (potassium salt of glyphosate, Roundup WeatherMAX; Monsanto) was mixed with $0.012 \mathrm{~g} \mathrm{ml}^{-1}$ AMS in water and applied to plants at a dosage of $0.42 \mathrm{~kg} \mathrm{ha}^{-1}$ in a spray chamber (DeVries Manufacturing Corp., 28081 8750th Avenue, Hollandale, MN 56045) calibrated to deliver $187 \mathrm{~L} \mathrm{ha}^{-1}$ at $206 \mathrm{kPa}$.

An aliquot $(625 \mu \mathrm{l})$ of the spray solution was fortified with ${ }^{14}$ C-labeled glyphosate (American Radiolabeled Chemicals, Inc., 101 Arc Drive, St. Louis, MO 63146) at a final ${ }^{14} \mathrm{C}$

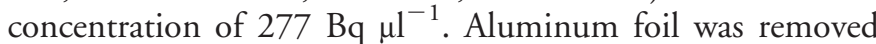
from the fourth youngest leaf, and $10 \mu \mathrm{l}$ of herbicide solution containing a total of $2,770 \mathrm{~Bq}$ of ${ }^{14} \mathrm{C}$-glyphosate solution was applied on the adaxial surface with a $10-\mu$ l dispensing pipette set to deliver 10 droplets, $1-\mu$ l each. Plants were returned to the greenhouse following treatment.

Plants were harvested $0,6,24,48$, and $72 \mathrm{~h}$ after treatment (HAT), according to methods described previously (Bukun et al. 2009). The treated leaf was excised and washed in $5 \mathrm{ml}$ of $10 \%$ (by vol) aqueous methanol with $0.25 \%$ nonionic surfactant (NIS). Unabsorbed ${ }^{14} \mathrm{C}$ in the leaf wash solution was quantified by liquid scintillation spectroscopy (LSS) (Packard Tri-Carb [Model 2500 TR], Packard Instrument Co., 800 Research Parkway, Meriden, CT 06450) with scintillation fluid (Ultima Gold LLT [6013371], PerkinElmer Life and Analytical Sciences, Inc., 940 Winter Street, Waltham, MA 02451). Plants were divided by cutting the shoot at the soil surface and sectioning into four parts: treated leaf, tissue above treated leaf (above treated tissue), aboveground tissue below treated leaf (below treated tissue), and roots. Plant parts were oven-dried at $60 \mathrm{C}$ for $48 \mathrm{~h}$, weighed, and combusted in a biological oxidizer (OX500, R. J. Harvey Instrument Co., 11 Jane Street, Tappan, NY 10983). Resulting $\mathrm{CO}_{2}$ was trapped in $10 \mathrm{ml}$ of ${ }^{14} \mathrm{C}$-trapping cocktail (OX-161, R. J. Harvey Instrument). Radioactivity exuded by roots was extracted from sand as described previously (Bukun et al. 2009). Radioactivity in all plant parts and root exudates was measured using LSS (Bukun et al. 2010).

The experiment was arranged in a split-split plot design, with harvest times as main plots, accessions as subplots, and plant parts as sub-subplots. Treatments were replicated three times, and two experiments were conducted. Absorption data were expressed as a percentage of ${ }^{14} \mathrm{C}$-glyphosate applied and were subjected to asymptotic regression in GraphPad Prism using the following two-parameter function:

$$
Y=A_{\max } \times[1-\exp (-b t)]
$$

where $Y$ is expressed as a percentage of the applied dose, $A_{\max }$ is the maximum percentage of applied ${ }^{14} \mathrm{C}$-glyphosate that was absorbed, $b$ is the relative slope, and $t$ is the time after application (Bukun et al. 2009, 2010; Kniss et al. 2011). Translocation data were expressed as the percentage of ${ }^{14} \mathrm{C}$ glyphosate recovered in plants and soil solution. Data were tested for normality in PROC UNIVARIATE of SAS software. To improve normality of residuals, the data were assigned ranks, and ANOVA was performed on the ranks (Conover 1999) in PROC MIXED. Sums of squares were partitioned according to a split-split plot experimental design. Fisher's Protected LSD test at $\mathrm{P} \leq 0.10,0.05$, and 0.01 was used to separate means (Steel and Torrie 1980) over a range 


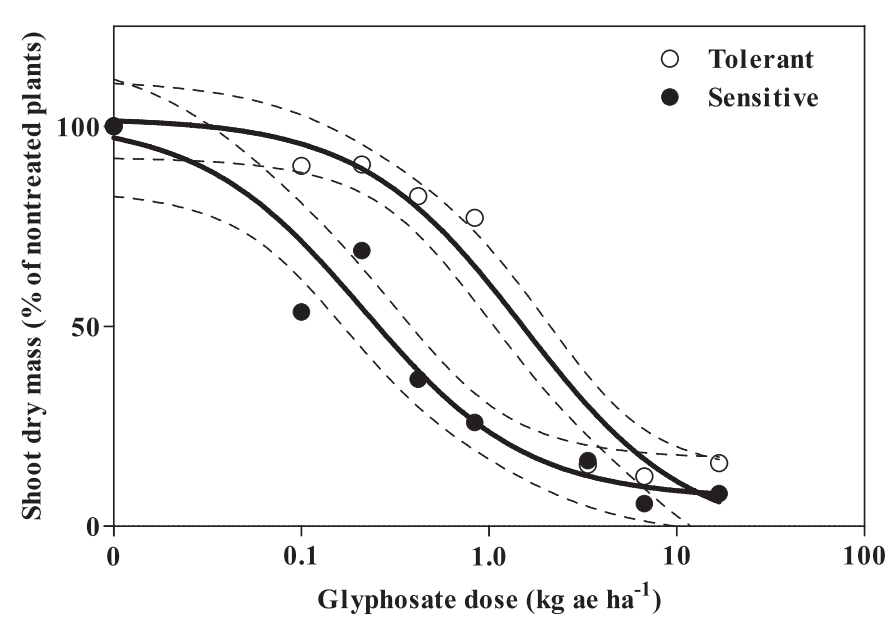

Figure 1. Shoot dry mass for tolerant (T) and sensitive (S) common lambsquarters in response to glyphosate $28 \mathrm{~d}$ after treatment. Predicted responses (solid lines) are described by $Y=95.2 /[1+\exp (1.6 \log x)-1.6 \log (1.6)], r^{2}=$ 0.99 ; and $Y=101.8 /[1+\exp (0.7 \log x)-0.7 \log (0.2)], r^{2}=0.98$, for $\mathrm{T}$ and $\mathrm{S}$ accessions, respectively. Dashed lines represent $95 \%$ confidence intervals for each accession. Data were pooled from two experiments for analysis.

of significance. To test experiment by harvest time and experiment by plant part interactions, PROC MIXED was performed using experiment as a fixed effect.

\section{Results and Discussion}

Whole-Plant Dose-Response. Experiment by accession interactions were not significant (data not shown), so data were pooled across experiments for analysis. The predicted $\mathrm{ED}_{50}$ value for the $\mathrm{T}$ accession $\left(1.6 \mathrm{~kg} \mathrm{ha}^{-1} \pm 0.4\right.$ standard error of the mean [SEM]) was eightfold greater than that of the $S$ accession $\left(0.2 \mathrm{~kg} \mathrm{ha}^{-1} \pm 0.2 \mathrm{SEM}\right)$ based on $95 \%$ confidence intervals (Figure 1). This result is largely consistent with Westhoven et al. (2008) who reported a $\mathrm{GR}_{50}$ value of $2.10 \mathrm{~kg} \mathrm{ha}^{-1} \mathrm{~kg}$ and a $\mathrm{T}: \mathrm{S}$ ratio of 3.7 for the $\mathrm{T}$ accession. The higher $T: S$ ratio in our research is partly attributed to the higher $\mathrm{GR}_{50}$ value $(0.57)$ for the sensitive Indiana biotype used by Westhoven et al. (2008). Reduced sensitivity to glyphosate in the range of 3- to 10-fold compared with a sensitive accession or biotype has also been observed in glyphosate-resistant horseweed [Conyza canadensis (L.) Cronq.] (Dinelli et al. 2006), Italian ryegrass [Lolium perenne L. ssp. multiflorum (Lam.) Husnot] (Perez-Jones et al. 2007), johnsongrass (Sorghum halepense [L.] Pers.) (Riar et al. 2011; Vila-Aiub et al. 2007), rigid ryegrass (Wakelin and Preston 2006), and giant ragweed (Ambrosia trifida L.) (Norsworthy et al. 2011; Stoltenberg et al. 2012).

EPSPS Sensitivity to Glyphosate. Because of significant experiment by accession interactions (data not shown), results from repeated experiments are presented separately (Figure 2). Both $\mathrm{T}$ and $\mathrm{S}$ accessions accumulated shikimate, and neither maximum accumulation (upper asymptotes) nor $\mathrm{ED}_{50}$ values differed between accessions for either experiment, as determined by $95 \%$ confidence intervals. Furthermore, no consistent differences were observed between accessions at low or high doses of glyphosate. Glyphosate-resistant horseweed treated at a lethal dose of glyphosate (the recommended field use rate) accumulated a similar level of shikimate relative to a sensitive biotype (Ge et al. 2010;

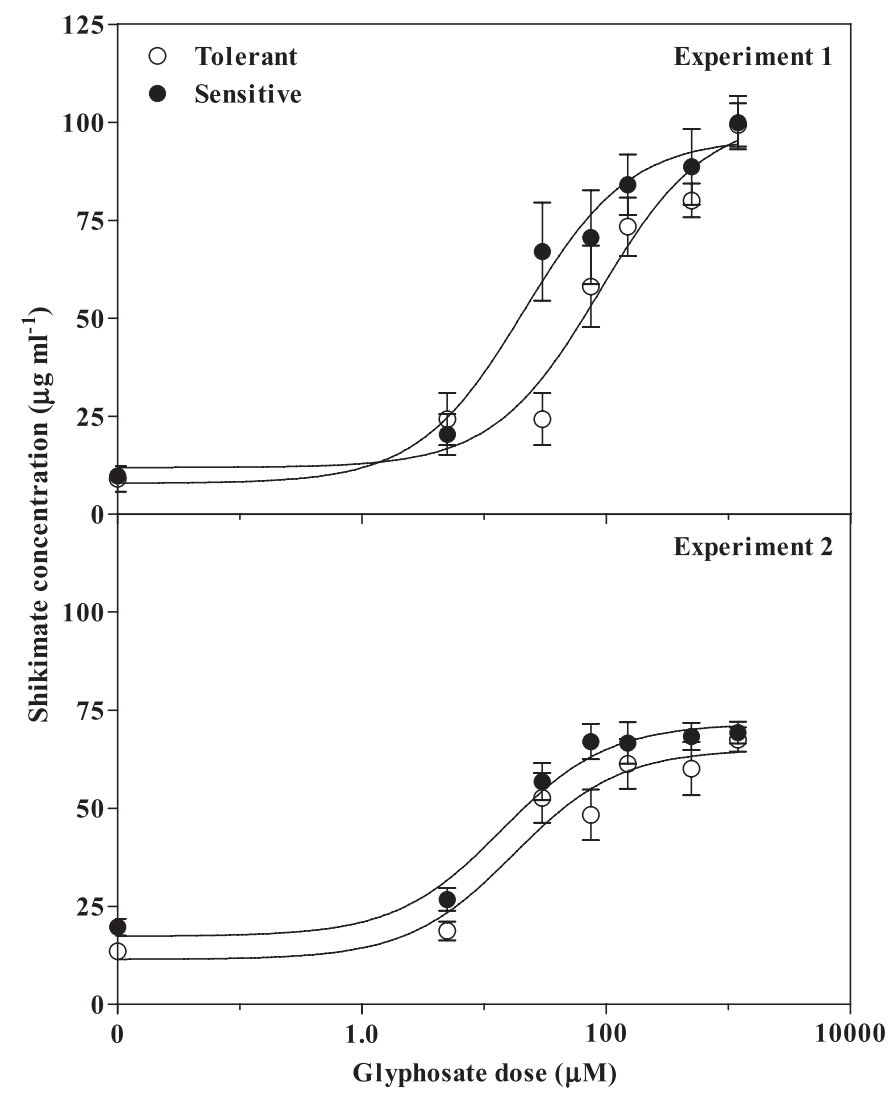

Figure 2. Shikimate concentration in tolerant $(\mathrm{T})$ and sensitive $(\mathrm{S})$ common lambsquarters at glyphosate doses ranging from 5 to $1,200 \mu \mathrm{M}$ after $24 \mathrm{~h}$ exposure. Experiment 1 response functions are described by $Y=11.9+89.5 /$ $\left(1+10^{\log 87.6-\log x}\right), r^{2}=0.75$; and $Y=7.9+88.0 /\left(1+10^{\log 21.2-\log x}\right), r^{2}=0.68$, for $\mathrm{T}$ and $\mathrm{S}$ accessions, respectively. Experiment 2 response functions are described by $Y=11.5+53.6 /\left(1+10^{\log 17.5-\log x}\right), r^{2}=0.67$; and $Y=17.4+54.2 /(1$ $+10^{\log 14.0-\log x}, r^{2}=0.80$, for $\mathrm{T}$ and $\mathrm{S}$ accessions, respectively. Bars indicate standard error of the mean.

Mueller et al. 2003), and a similar level to that accumulated in the $\mathrm{T}$ and $\mathrm{S}$ accessions of common lambsquarters. However, resistant horseweed biotypes accumulated less shikimate than did sensitive biotypes at nonlethal doses of glyphosate (Feng et al. 2004; Koger and Reddy 2005).

Horseweed is a species known to sequester glyphosate in the vacuole (Ge et al. 2010). Resistant weed biotypes bearing mechanisms of resistance to glyphosate other than vacuolar sequestration tend to accumulate less shikimate following exposure to glyphosate relative to sensitive control plants. These include increased EPSPS protein abundance in Palmer amaranth (Gaines et al. 2010) and altered translocation away from meristematic zones in rigid ryegrass from Australia (Preston et al. 2006; Wakelin et al. 2004) and Italian ryegrass from Oregon (Perez-Jones et al. 2007). Most notably, resistant biotypes of Italian ryegrass from Chile with a Pro $_{106}$ mutation, conferring an altered EPSPS target site, accumulated less shikimate than did sensitive control plants (Perez-Jones et al. 2007). Our results suggest that decreased sensitivity of EPSPS to glyphosate is not the mechanism of glyphosate tolerance in the $\mathrm{T}$ accession of common lambsquarters.

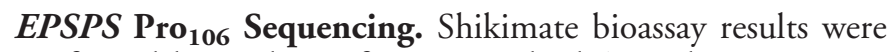
confirmed by analysis of EPSPS in both $\mathrm{T}$ and $\mathrm{S}$ accessions. Missense mutations to Pro $\mathrm{Pr}_{106}$ that would confer decreased 
Lolium rigidum

Oryza sativa

Arabidopsis thaliana

Nicotiana tabacum

Phaseolus vulgaris

Amaranthus palmeri

Chenopodium album (S)

Chenopodium album (T)
CTGGAACTGCGATGCGGC̈CATTGACGGCTGCTG CTGGAACTGCAATGCGACCATTGACAGCAGCCG CAGGAACAGCAATGCGTCCACTTACCGCTGCGG CAGGAACAGCAATGCGGCCATTGACGGCAGCAG CAGGAACAGCAATGCGTCCACTTACCGCTGCGG CAGGAACAGCGATGCGCCCATTGACAGCTGCGG CAGGAACAGCAATGCGTCCATTGACAGCCGCAG CAGGAACAGCAATGCGTCCATTGACAGCCGCAG

Figure 3. Partial DNA ( $5^{\prime}$ to $\left.3^{\prime}\right)$ sequences of EPSPS, the gene encoding EPSPS from glyphosate-tolerant $(\mathrm{T})$ and glyphosate-sensitive $(\mathrm{S})$ common lambsquarters aligned with complementary DNA or messenger RNA sequences of rigid ryegrass (GenBank AF349754.1), rice (Oryza sativa L.; GenBank AF413082.1), mouse-ear cress (GenBank AK227120.1), cultivated tobacco (GenBank M61904.1), kidney bean (GenBank DQ813667.1), and Palmer amaranth (GenBank FJ861242.1). An asterisk indicates the Pro ${ }_{106}$ codon known to undergo a missense mutation that confers tolerance to glyphosate in the mature enzyme.

sensitivity to glyphosate were not observed (Figure 3). Furthermore, no nucleotide changes between $T$ and $S$ accessions were evident at any site along the 300-bp fragment amplified (data not shown). These results are consistent with a nontarget site mechanism of tolerance to glyphosate (Powles and Yu 2010; Shaner 2009) and further suggest that reduced binding of glyphosate to EPSPS is not the mechanism of tolerance in the $\mathrm{T}$ accession of common lambsquarters.

EPSPS Protein Abundance. An immunoblot probed with anti-EPSPS antibody indicated that EPSPS protein band intensity for $T$ and $S$ accessions of common lambsquarters (lanes 20 to 21 and lanes 1 to 2, respectively, in Figure 4) was equal to or less than that of a single-copy glyphosate-sensitive kochia control (lane 10). In contrast, protein band intensity for glyphosate-resistant Palmer amaranth (lane 6) was consistent with previous results wherein EPSPS genomic copy number was positively correlated with increased EPSPS protein abundance (Gaines et al. 2010). Increased band intensity was also observed in glyphosate-resistant kochia (lanes 7 to 9), known to have an increased EPSPS proteinabundance mechanism of glyphosate resistance as well (P. Westra, unpublished data), relative to the single-copy sensitive control (lane 10). Although common lambsquarters should
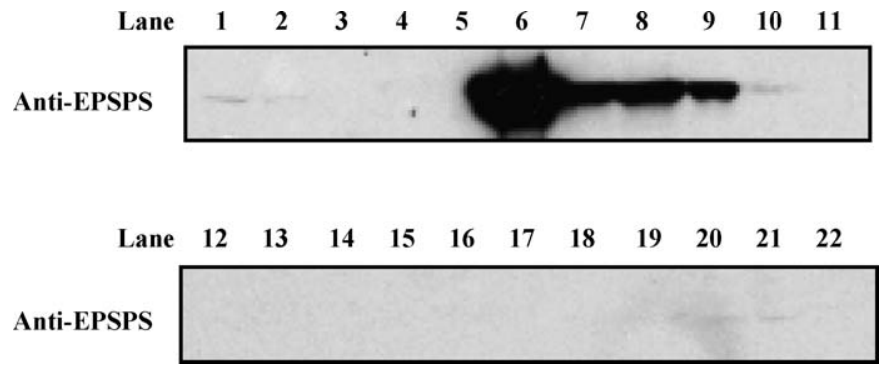

Figure 4. Characterization of EPSPS protein separated by sodium dodecyl sulfate-polyacrylamide gel electrophoresis, transblotted, and probed with antiEPSPS polyclonal antibody. Lanes 1 to $4,2.5-\mathrm{cm}$-tall glyphosate-sensitive common lambsquarters; lane 5, blank; lane 6, glyphosate-resistant Palmer amaranth with approximately 85 copies of EPSPS; lanes 7 to 9, glyphosateresistant kochia with 8, 7, and 5 copies of EPSPS, respectively; lane 10, glyphosate-sensitive kochia with a single copy of EPSPS; lane 11, blank; lanes 12 to 14,8 -cm-tall glyphosate-tolerant common lambsquarters; lanes 15 to 18,8 $\mathrm{cm}$-tall glyphosate-sensitive common lambsquarters; lanes 19 to $22,2.5-\mathrm{cm}$-tall glyphosate-tolerant common lambsquarters. Common lambsquarters, Palmer amaranth, and glyphosate-sensitive kochia lanes contained $25 \mu \mathrm{g}$ protein lane ${ }^{-1}$, whereas glyphosate-resistant kochia lanes contained $12.5 \mu \mathrm{g}$ protein lane ${ }^{-1}$, such that band intensity in lanes 7 to 9 corresponded to approximately 4, 3.5, and 2.5 copies of EPSPS, respectively.

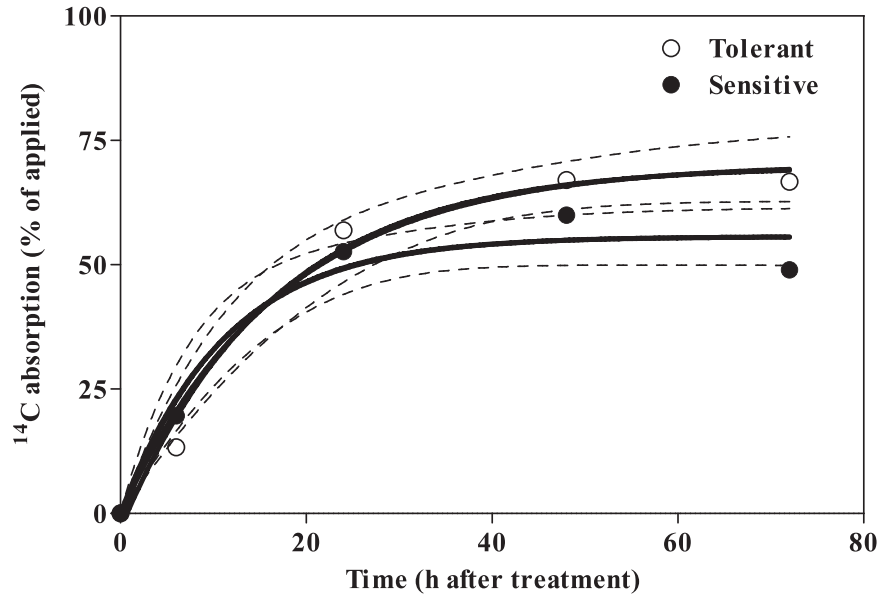

Figure 5. Foliar absorption of ${ }^{14} \mathrm{C}$-glyphosate in glyphosate-tolerant and glyphosate-sensitive common lambsquarters during a 72-h time course. Predicted responses (solid lines) are described by $Y=70.3[1-\exp (-0.06 x)], r^{2}=0.90$; and $\left.Y=55.7[1-\exp (-0.09 x)], r^{2}=0.85\right)$ for the tolerant and sensitive accessions, respectively. Dashed lines represent $95 \%$ confidence intervals for each accession. Data were pooled from two experiments for analysis.

theoretically have three copies of the EPSPS gene in its hexaploid genome vs. kochia's single copy (kochia is diploid, $2 n=1 \mathrm{x}=18)$, our results suggest that ploidy level may not have a one-to-one relationship with EPSPS protein abundance when compared across these species. This finding could be due to many factors, including differential gene regulation among species and unique mechanisms for gene amplification. Regardless, our methods were able to detect relative differences in EPSPS protein abundance over a wide range, and the results suggest that increased EPSPS protein abundance is not the mechanism of glyphosate tolerance in the $T$ accession of common lambsquarters.

Glyphosate Absorption, Translocation, and Exudation from Roots. The experiment by treatment interaction for glyphosate absorption, translocation, and exudation was not significant $(P \geq 0.05)$, so data were pooled, and experiment was treated as a random effect for analysis. Recovery of ${ }^{14} \mathrm{C}$ was $95 \%$ or greater immediately following application of ${ }^{14} \mathrm{C}$ glyphosate and $80 \%$ or greater across accessions, harvest times, and experiments. Recovery levels were consistent with those for common lambsquarters in previous research (Kniss 2006). Absorption was slightly greater in the $T$ accession than in the $S$ accession at 48 and 72 HAT as determined by $95 \%$ confidence intervals (Figure 5). Reduced ${ }^{14} \mathrm{C}$ absorption may have been due to phytotoxicity of glyphosate on some of the treated $S$ plants. Phytotoxicity was presumably due to greater sensitivity in the $S$ accession or the larger droplet size $(1 \mu \mathrm{l})$ when ${ }^{14} \mathrm{C}$ glyphosate was applied by hand as opposed to field and greenhouse applications made via an overhead spray nozzle (Ryerse et al. 2004) or both.

Less than $25 \%$ of absorbed ${ }^{14} \mathrm{C}$ translocated out of the treated leaf in both $\mathrm{T}$ and $\mathrm{S}$ accessions (Figure $6 \mathrm{~A}$ ). ${ }^{14} \mathrm{C}$ translocation to tissue above the treated leaf differed between accessions at 24, 48, and $72 \mathrm{HAT}(\mathrm{P} \leq 0.05,0.01$, and 0.10 , respectively), such that the $S$ accession translocated a greater percentage of absorbed ${ }^{14} \mathrm{C}$ to the area above the treated leaf (Figure 6B). ${ }^{14} \mathrm{C}$ translocation to aboveground tissue below the treated leaf (Figure 6C) and to root tissue (Figure 6D) remained below $10 \%$ of that absorbed and did not differ 

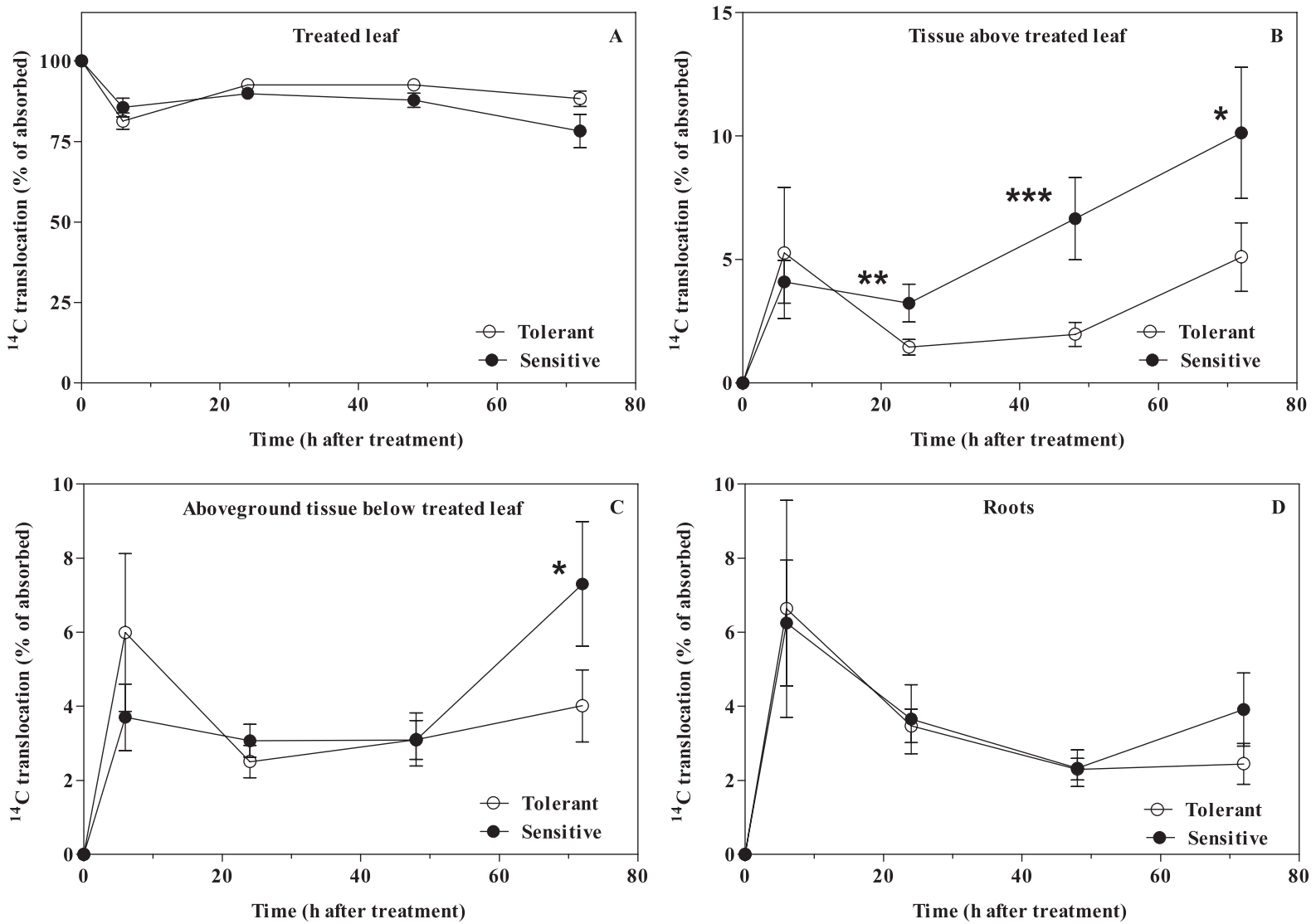

Figure 6. Distribution of absorbed ${ }^{14} \mathrm{C}$ in the (A) treated leaf, (B) tissue above the treated leaf, (C) aboveground tissue below the treated leaf, and (D) roots of glyphosate-tolerant and glyphosate-sensitive common lambsquarters during a 72 -h time course after treatment with ${ }^{14} \mathrm{C}$-glyphosate. One, two, or three asterisks indicate a difference between accessions at $\mathrm{P} \leq 0.10,0.05$, and 0.01 , respectively, as determined by Fisher's Protected LSD test, within harvest interval. Data were pooled from two experiments for analysis. Bars indicate standard error of the mean.

between accessions at any harvest time $(\mathrm{P}=0.05)$. However, at $\mathrm{P}=0.10$, a greater percentage of absorbed ${ }^{14} \mathrm{C}$ was translocated to aboveground tissue below the treated leaf in the $S$ accession than it was in the $\mathrm{T}$ accession at 72 HAT (Figure 6C). Radioactivity in the soil solution was less than $2 \%$ of absorbed ${ }^{14} \mathrm{C}$ at all harvest times and did not differ between accessions (data not shown).

Decreased translocation to meristematic tissue has been reported in several glyphosate-resistant species, including rigid ryegrass (Wakelin et al. 2004; Yu et al. 2009), horseweed (Feng et al. 2004; Koger and Reddy 2005), Italian ryegrass in Oregon (Michitte et al. 2007; Perez-Jones et al. 2007), and johnsongrass (Powles and Yu 2010; Riar et al. 2011). Although we did not quantify ${ }^{14} \mathrm{C}$ in the apical meristem, reduced translocation of ${ }^{14} \mathrm{C}$ to the area above the treated leaf suggests that altered translocation may be the primary mechanism of tolerance to glyphosate in the $\mathrm{T}$ accession of common lambsquarters. However, reduced sensitivity to glyphosate in a rigid ryegrass population from South Africa is conferred by a $\mathrm{Pro}_{106}$ mutation and another unidentified mechanism not linked to metabolism or translocation acting additively (Kaundun et al. 2011). In addition, vacuolar sequestration and glyphosate metabolism were not addressed in our research, such that the possibility for multiple mechanisms of tolerance to occur in the T accession of common lambsquarters cannot be ruled out.

Our results confirmed tolerance of a common lambsquarters accession from Indiana to glyphosate compared with an accession from Wisconsin that has no history of exposure to glyphosate in the field and whose sensitivity to glyphosate was similar to several other accessions from treatments with wellcharacterized glyphosate use. The $\mathrm{ED}_{50}$ value for the $\mathrm{T}$ accession $\left(1.6 \mathrm{~kg} \mathrm{ha}^{-1}\right)$ was eightfold greater than that of the $S$ accession $\left(0.2 \mathrm{~kg} \mathrm{ha}^{-1}\right)$ based on $95 \%$ confidence intervals. Tolerance was not due to decreased EPSPS sensitivity to glyphosate (as estimated by in vivo shikimate accumulation in leaf tissue), a missense mutation at the $\mathrm{Pro}_{106}$ codon, or overabundance of EPSPS protein. However, a greater percentage of absorbed ${ }^{14} \mathrm{C}$-glyphosate was translocated to tissue above the treated leaf, which included the shoot apical meristem, in the $S$ accession than the $T$ accession. These results suggest an important role of reduced translocation in conferring tolerance of common lambsquarters to glyphosate. Additional research is needed to determine whether vacuolar sequestration or impaired phloem loading play a role in the tolerant accession.

\section{Acknowledgments}

We thank Dr. R. Douglas Sammons, Monsanto Company, for providing the anti-EPSPS primary antibody.

\section{Literature Cited}

Amrhein, N., B. Deus, P. Gherke, and H. C. Steinruken. 1980. The site of inhibition of the shikimate pathway by glyphosate, II: interference of 
glyphosate with chorismate formation in vivo and in vitro. Plant Physiol. 66:830-834.

Bhargava, A., S. Shukla, and D. Ohri. 2006. Karyotypic studies on some cultivated and wild species of Chenopodium (Chenopodiaceae). Genet. Resour. Crop Evol. 53:1309-1320.

Bolt, M. W. and P. A. Mahoney. 1997. High-efficiency blotting of proteins of diverse sizes following sodium dodecyl sulfate-polyacrylamide gel electrophoresis. Anal. Biochem. 247:185-192.

Bukun, B., R. B. Lindenmayer, S. J. Nissen, P. H. Westra, D. L. Shaner, and G. Brunk. 2010. Absorption and translocation of aminocyclopyrachlor and aminocyclopyrachlor-methyl ester in Canada thistle (Cirsium arvense). Weed Sci. 58:96-102.

Bukun, B., T. A. Gaines, S. J. Nissen, P. H. Westra, G. Brunk, D. L. Shaner, B. B. Sleugh, and V. F. Peterson. 2009. Aminopyralid and clopyralid absorption and translocation in Canada thistle (Cirsium arvense). Weed Sci. 57:10-15.

Conley, S. P., D. E. Stoltenberg, C. M. Boerboom, and L. K. Binning. 2003. Predicting soybean yield loss in giant foxtail (Setaria faberi) and common lambsquarters (Chenopodium album) communities. Weed Sci. 51:402-407.

Conn, J. S. and N. R. Werdin-Pfisterer. 2010. Variation in seed viability and dormancy of 17 weed species after 24.7 years of burial: the concept of buried seed safe sites. Weed Sci. 58:209-215.

Conover, W. J. 1999. Some methods based on ranks. Pp. 269-427 in B. W. Wiley, ed. Practical Nonparametric Statistics. 3rd ed. New York: J. Wiley.

Darmency, H. and J. Gasquez. 1990. Appearance and spread of triazine resistance in common lambsquarters (Chenopodium album). Weed Technol. 4:173-177.

Dinelli, G., I. Marotti, A. Bonetti, M. Minelli, P. Catizone, and J. Barnes. 2006 Physiological and molecular insight on the mechanisms of resistance to glyphosate in Conyza canadensis (L.) Cronq. biotypes. Amsterdam: Elsevier. 12 p.

Feng, P.C.C., M. Tran, T. Chiu, R. D. Sammons, G. R. Heck, and C. A. Cajacob. 2004. Investigations into glyphosate-resistant horseweed (Conyza canadensis): retention, uptake, translocation and metabolism. Weed Sci. 52:498-505.

Gaines, T. A., W. L. Zhang, D. Wang, B. Bukun, S. T. Chisholm, D. L. Shaner, S. J. Nissen, W. K. Vencill, R. D. Sammons, J. Jiang, C. Preston, J. E. Leach, and P. H. Westra. 2010. Gene amplification confers glyphosate resistance in Amaranthus palmeri. Proc. Natl. Acad. Sci. U. S. A. 107:1029-1034.

Ge, X., D. A. D'avignon, J.J.H. Ackerman, and R. D. Sammons. 2010. Rapid vacuolar sequestration: the horseweed glyphosate resistance mechanism. Pest Manag. Sci. 66:345-348.

Hall, T. A. 1999. BioEdit: a user-friendly biological sequence alignment editor and analysis program for Windows 95/98/NT. Nucleic Acids Symp. Ser. 41:95-98.

Harrison, S. K. 1990. Interference and seed production by common lambsquarters (Chenopodium album) in soybeans (Glycine max). Weed Sci. 38:113-118.

Heap, I. 2012. The International Survey of Herbicide Resistant Weeds http:// www.weedscience.com/. Accessed February 3, 2012.

Herrmann, K. M. and L. M. Weaver. 1999. The shikimate pathway. Annu. Rev. Plant Physiol. Mol. Biol. 50:473-503.

Hite, G. A., S. R. King, E. S. Hagood, and G. I. Holtzman. 2008. Differential response of a Virginia common lambsquarters (Chenopodium album) collection to glyphosate. Weed Sci. 56:203-209.

Holm, L. G., D. L. Plucknett, J. V. Pancho, and J. P. Herberger. 1977. Chenopodium album L., Pp. 84-91 in The World's Worst Weeds: Distribution and Biology. Honolulu, HI: University Press of Hawaii, Honolulu.

Kaundun, S. S., R. P. Dale, I. A. Zelaya, G. Dinelli, I. Marotti, E. Mcindoe, and A. Cairns. 2011. A novel P106L mutation in EPSPS and an unknown mechanism(s) act additively to confer resistance to glyphosate in a South African Lolium rigidum population. J. Agric. Food Chem. 59:3227-3233.

Kniss, A. R. 2006. Tolerance of common lambsquarters (Chenopodium album L.) to glyphosate. Ph.D dissertation. Laramie, WY: University of Wyoming. 92 p.

Kniss, A. R., J. D. Vassios, S. J. Nissen, and C. Ritz. 2011. Nonlinear regression analysis of herbicide absorption studies. Weed Sci. 59:601-610.

Kniss, A. R., S. D. Miller, P. H. Westra, and R. G. Wilson. 2007. Glyphosate susceptibility in common lambsquarters (Chenopodium album) is influenced by parental exposure. Weed Sci. 55:572-577.

Koger, C. H. and K. N. Reddy. 2005. Role of absorption and translocation in the mechanism of glyphosate resistance in horseweed (Conyza canadensis). Weed Sci. 53:84-89.

Kruger, G. R., W. G. Johnson, S. C. Weller, M.D.K. Owen, D. R. Shaw, J. W. Wilcut, D. L. Jordan, R. G. Wilson, M. L. Bernards, and B. G. Young. 2009. U.S. grower views on problematic weeds and changes in weed pressure in glyphosate-resistant corn, cotton, and soybean cropping systems. Weed Technol. 23:162-166.

Laemmli, U. K. 1970. Cleavage of structural proteins during the assembly of the head of bacteriophage T4. Nature 227:680-685.

Michitte, P., R. De Prado, N. Espinoza, J. P. Ruiz-Santaella, and C. Gauvrit. 2007. Mechanisms of resistance to glyphosate in a ryegrass (Lolium multiflorum) biotype from Chile. Weed Sci. 55:435-440.

Moechnig, M. J., D. E. Stoltenberg, C. M. Boerboom, and L. K. Binning. 2003. Empirical corn-yield loss estimation from common lambsquarters (Chenopodium album) and giant foxtail (Setaria faberi) in mixed communities. Weed Sci. 51:386-393.

Mueller, T. C., J. H. Massey, R. M. Hayes, C. L. Main, J. Stewart, and C. N. 2003 Shikimate accumulates in both glyphosate-sensitive and glyphosate-resistant horseweed (Conyza canadensis L. Cronq.). J. Agric. Food Chem. 51:680-684.

Norsworthy, J. K., D. S. Riar, P. Jha, and R. C. Scott. 2011. Confirmation, control, and physiology of glyphosate-resistant giant ragweed (Ambrosia trifida) in Arkansas. Weed Technol. 25:430-435.

Perez-Jones, A. K., K. W. Park, N. Polge, J. Colquhoun, and C. Mallory-Smith. 2007. Investigating the mechanisms of glyphosate resistance in Lolium multiflorum. Planta 226:395-404.

Powles, S. B. and C. Preston. 2006. Evolved glyphosate resistance in plants: biochemical and genetic basis of resistance. Weed Technol. 20:282-289.

Powles, S. B. and Q. Yu. 2010. Evolution in action: plants resistant to herbicides. Annu. Rev. Plant Biol. 61:317-347.

Preston, C., D. L. Shaner, P. H. Westra, A. S. Culpepper, T. L. Grey, W. K. Vencill, and A. M. Wakelin. 2006. Can a shikimate assay be used to determine the genotype of glyphosate resistant plants for population genetic studies? Pp. 511-514 in C. Preston, J. H. Watts, and N. D. Crossman, eds. Managing Weeds in a Changing Climate: Papers and Proceedings of the 15th Australian Weeds Conference. Adelaide, South Australia: Council of Australasian Weed Societies.

Riar, D. S., J. K. Norsworthy, D. B. Johnson, R. C. Scott, and M. Bagavathiannan. 2011. Glyphosate resistance in a johnsongrass (Sorghum halepense) biotype from Arkansas. Weed Sci. 59:299-304.

Ritz, C. 2010. Toward a unified approach to dose-response modeling in ecotoxicology. Environ. Toxicol. Chem. 29:220-229.

Rogers, S. O. and A. J. Bendich. 1985. Extraction of DNA from milligram amounts of fresh, herbarium, and mummified plant tissues. Plant Mol. Biol. 5:69-76.

Ryerse, J. S., R. A. Downer, R. D. Sammons, and P.C.C. Feng. 2004. Effect of glyphosate spray droplets on leaf cytology in velvetleaf (Abutilon theophrasti). Weed Sci. 52:302-309.

Saini, H. S., P. K. Bassi, and M. S. Spencer. 1986. Use of ethylene and nitrate to break seed dormancy of common lambsquarters (Chenopodium album). Weed Sci. 34:502-506.

Shaner, D. L. 2009. Role of translocation as a mechanism of resistance to glyphosate. Weed Sci. 57:118-123.

Shaner, D. L., R. B. Lindenmeyer, and M. H. Ostlie. 2012. What have the mechanisms of resistance to glyphosate taught us? Pest. Manag. Sci. 68:3-9.

Shaner, D. L., T. Nadler-Hassar, W. B. Henry, and C. H. Koger. 2005. A rapid in vivo shikimate accumulation assay with excised leaf discs. Weed Sci. 53:769-774.

Sivesind, E. C., J. M. Gaska, M. R. Jeschke, C. M. Boerboom, and D. E. Stoltenberg. 2011. Common lambsquarters response to glyphosate across environments. Weed Technol. 25:44-50.

Steel, R.G.D. and J. H. Torrie. 1980. Principles and procedures of statistics: A biometrical approach. 2nd ed. New York: McGraw-Hill. 633 p.

Stoltenberg, D. E. and R. J. Wiederholt. 1995. Giant foxtail (Setaria faberi) resistance to aryloxyphenoxypropionate and cyclohexanedione herbicides. Weed Sci. 43:527-535.

Stoltenberg, D., M. Yerka, C. Glettner, J. Stute, and T. Trower. 2012. Giant ragweed resistance to glyphosate in Wisconsin. Wis. Crop Manager. 19:43-44. http://ipcm.wisc.edu/wcm/ Accessed June 21, 2012.

Vila-Aiub, M. M., M. C. Balbi, P. E. Gundel, C. M. Ghersa, and S. B. Powles. 2007. Evolution of glyphosate-resistant johnsongrass (Sorghum halepense) in glyphosate-resistant soybean. Weed Sci. 55:566-571.

Wakelin, A. M. and C. Preston. 2006. Inheritance of glyphosate resistance in several populations of rigid ryegrass (Lolium rigidum) from Australia. Weed Sci. 54:212-219

Wakelin, A. M., D. F. Lorraine-Colwill, and C. Preston. 2004. Glyphosate resistance in four different populations of Lolium rigidum is associated with reduced translocation of glyphosate to meristematic zones. Weed. Res. 44:453-459.

[WSSA] Weed Science Society of America. 1998. Herbicide resistance and herbicide tolerance defined. Weed Technol. 12:789.

Westhoven, A. M., G. R. Kruger, C. K. Gerber, J. M. Stachler, M. M. Loux, and W. G. Johnson. 2008. Characterization of selected common lambsquarters (Chenopodium album) biotypes with tolerance to glyphosate. Weed Sci. 56:685-691.

Yerka, M. K. 2011. Glyphosate tolerance and gene flow in common lambsquarters (Chenopodium album L.) Ph.D dissertation. Madison, WI: University of Wisconsin-Madison. 119 p.

Yerka, M. K., N. de Leon, and D. E. Stoltenberg. 2012. Pollen-mediated gene flow in common lambsquarters (Chenopodium album). Weed Sci. 60:600-606.

Yu, Q., I. Abdallah, H. P. Han, M. Owen, and S. B. Powles. 2009. Distinct nontarget-site mechanisms endow resistance to glyphosate, ACCase and ALS-inhibiting herbicides in multiple herbicide-resistant Lolium rigidum populations. Planta 230:713-723.

Received October 2, 2012, and approved January 29, 2013. 